\title{
The Effect of Annealing Temperature on Microstructure and Mechanical Properties of Lightweight Steel with Increased Aluminium Content
}

Ludmila Kučerová, Martin Bystrianský, Štěpán Jeníček

Regional Technological Institute, University of West Bohemia in Pilsen, Univerzitní 8, 30614 Plzeň. Czech Republic. Email: skal@rti.zcu.cz,mbyst@rti.zcu.cz,jeniceks@rti.zcu.cz

\begin{abstract}
A demand for enlightening of constructions in an automotive industry resulted in an intensive development of high strength steels and in attempts to decrease the weight of the steel by intensive alloying by lighter elements. This work used chemical concept of AHSS (advanced high strength steel) TRIP (transformation induced plasticity) steel with $0.2 \% \mathrm{C}$ and micro-alloyed by $0.06 \% \mathrm{Nb}$ and increased manganese content to $4 \%$ and aluminium to $6.5 \%$ to produce lightweight steel, which was cast and re-forged and subsequently annealed at various temperatures in the range of $300^{\circ} \mathrm{C}-8^{\circ} 0^{\circ} \mathrm{C}$. The resulting microstructures were analysed by light microscopy, laser scanning confocal microscopy, scanning electron microscopy and $X$-ray diffraction phase analysis and mechanical properties were measured by a tensile test. Tensile strengths in the region of $600 \mathrm{MPa}-757 \mathrm{MPa}$ and total elongations around $20 \%$ were obtained for annealed samples.
\end{abstract}

Keywords: aluminium alloyed steel, light-weight steel, annealing, microstructure

\section{Acknowledgement}

This contribution has been prepared within the project LO1502 'Development of the Regional Technological Institute' under the auspices of the National Sustainability Programme I of the Ministry of Education of the Czech Republic aimed at supporting research, experimental development and innovation.

\section{References}

[1] KUČEROVÁ, L., BYSTRIANSKÝ, M., JENÍČEK, M., FRANCISKO, P. (2017). Effect of deformation conditions on microstructure and mechanical properties of low alloyed steel, In: Manufacturing Technology, Vol. 17, No. $5,752-756$.

[2] KUČEROVÁ, L., JIRKOVÁ, H., KÁŇA, J. (2016). The suitability of 42SiCr steel for Quenching and Partitioning Process. In: Manufacturing Technology, Vol. 16, No. 5, 984-989.

[3] WU, Z. Q. DING, H., AN, X.H., HAN, D., LIAO, X.Z. (2015). Influence of Al content on the strain-hardening behaviour of aged low density Fe-Mn-Al-C steels with high Al content. In: Materials Scinece and Engineering A, Vol. 639, 187-191.

[4] SUH, Dong-Woo, KIM, Nack J. (2013). Low-density steels. In: Scripta Materialia, Vol. 68, 337-338.

[5] KIM, H., SUH, D.-W., FIM, N.J. (2013). Fe-Al-Mn-C lightweight structural alloys: a review on the microstructures and mechanical properties, In: Sci. Technol. Adv. Mater., Vol. 14, 1-11.

[6] RANNA, R., LIU, C., RAY, R.K. (2014). Evolution of microstructure and mechanical properties during thermomechanical processing of a low-density multiphase steel for automotive application, In: Acta materialia, Vol. 75, 227-245.

[7] XUA, R-CH., et al. (2017). Microstructures and mechanical properties of ferrite-based lightweight steel with different compositions, In: Journal of Iron and Steel Research, International, Vol. 24, Is. 7, 737-742.

[8] CHOO, W.K., KIM, J.H., YOON, Y.C. (1997). Microstructural change in austenitic Fe-30.0wt\%Mn-7.8wt\%Al$1.3 \mathrm{wt} \% \mathrm{C}$ initiated by spinodal decomposition and its influence on mechanical properties In: Acta Mater, Vol. 45, 4877.

[9] LU, W.J., ZHAND, X.F. QIN, R.S. (2015). K-carbide hardening in a low-density high-Al high-Mn multiphase steel, In: Materials Letters, Vol. 138, 96-99.

[10] SOHN, S.S., SONG, H., SUH, B.-C., KWAK, J.-H., LEE, B.-J., KIM, N.J., LEE, S. (2015). Novel ultra-highstrength (ferrite + austenite) duplex lightweight steels achieved by fine dislocation substructures (Taylor lattices), grain refinement, and partial recrystallization, In: Acta Mater., Vol. 96, 301-310.

[11] FROMMEYER, G. (2006). Microstructures and Mechanical Properties of High $\square$ Strength Fe $\square \mathrm{Mn} \square \mathrm{Al} \square \mathrm{C}$ Light $\square$ Weight TRIPLEX Steels, In: Steel Res Int, Vol. 77, 627. 
[12] JOHANSSON, J., ODEN, M., ZHENG, X.H. (1999). Evolution of the residual stress state in a duplex stainless steel during loading, In: Acta Mater, Vol. 47, 2669.

[13] PARK, S.J., et al. (2013). Microstructure and tensile behaviour of duplex low-density steel containing 5 mass \% aluminium, In: Scripta Materialia, Vol. 68, 365-369.

[14] SEO, C-H., et al. (2011). Effect of Carbon Content on Cracking Phenomenon Occurring during Cold Rolling of Three Light-Weight Steel Plates, In: Metall. Mater. Trans., Vol. 42A, 138-146.

[15] KUZIAK, R., KAWALLA, R., WAENGLER, S. (2008). Advanced high strength steels for automotive industry, In: Arch. Civ. Mech. Eng., Vol. 8, 103-117.

[16] LU, W.J., QIN, R.S. (2016). Influence of $\kappa$-carbide interface structure on the formability of lightweight steels, In: Materials and Design, Vol. 104, 211-216.

[17] LEE, S., JEONG, J., LEE, Y.-K. (2015). Precipitation and dissolution behavior of k-carbide during continuous heating in Fe-9.3Mn-5.6Al-0.16C lightweight steel, In: Journal of Alloys and Compounds, Vol. 648, 149-153.

[18] SEOL, J.-B., RAABE, D., CHOI, P., PARK, H.-S., KWAKC, J.-H., PARK, CH.-G. (2013). Direct evidence for the formation of ordered carbides in a ferrite-based low-density Fe-Mn-Al-C alloy studied by transmission electron microscopy and atom probe tomography. In: Scripta Materialia, Vol. 68, 348-353.

Copyright (C) 2017. Published by Manufacturing Technology. All rights reserved. 